2. Peredyriy, V. A. (2002). Kalendar-al'manakh yak typ periodychnoho vydannya (za materialamy halyts'koyi presy 20-30-kh rr. XIX st.). Ukrayins'ka periodyka: Istoriya ta suchasnist'. L'viv, p. 526-529.

3. Franko, I. (1984). Ukrayins 'ka al'manakhova literatura: Zb. Tvoriv: u 50 t., t. 27, Kiev, p. 107.

4. Franko, I. (1984). Al'manakh chy hazeta: Zb. Tvoriv: u 50 t. T. 28. Kiev, p. 197.

5. Rusova, S. (1934). Nashi vyznachni zhinky: Literaturni kharakterystyky i syluety. Vinnipeh, $92 \mathrm{p}$.

6. Peredyriy, V. (1995). Halyts'ka periodyka dlya zhinok: stanovlennya, rozvytok, problematyka (1853-1939 rr.). Zbirnyk prats' naukovo-doslidnoho tsentru periodyky, vyp. 2, L'viv, p. 44-63.

Матеріал надійшов до редакиії 13.01.2021 p.

УДК 327(477):314.151]:316.48

\title{
Антоніна Шуляк,
}

доктор політичних наук, професор кафедри міжнародних комунікацій

та політичного аналізу, декан факультету міжнародних відносин, Волинський національний університет імені Лесі Українки, ORCID ID 0000-0002-5234-0758 antonina.mytko@vnu.edu.ua DOI 10.29038/2524-2679-2021-01-333-344

\section{ТЕНДЕНЦІЇ МІГРАЦІЙНИХ ПРОЦЕСІВ ЯК ЧИННИКА ПІДВЩЕННЯ КОНФЛІКТОГЕННОСТІ}

У статті міграцію населення розглянуто як складний комплексний процес, що досліджується фахівиями багатьох спеціальностей. Зазначено, щяо міграція та безпека пов'язані не лише прямим, а й зворотним зв'язком, тобто безпекові заходи держав впливають на переміщення населення. Основними тенденціями міграцій населення в Україні в період між останнім його переписом у Радянському Союзі в 1989 р. та першим у незалежній Україні у 2001 р. були зниження загального рівня мобільності населення; зменшення інтенсивності міграційних зв'язків із колишніми республіками СРСР; розширення контактів із країнами пострадянського табору; набуття міграиіями більш «сімейного» характеру; поява і розвиток нових

(C) Шуляк А., 2021 
для пострадянського простору форм міграиійних переміщень. Після 2014 р. та подій на Донбасі й у Криму додалася ще одна причина - вимушена міграиія внаслідок гібридної війни. Розглянуто прогнози зміни чисельності населення України, міграчії украӥнців за кордон і прибуття мігрантів та біженців до намої держави до 2050 р. за даними украӥнських дослідницьких інститутів. Ключові слова: міграційні прочеси, біжениі, конфліктогенність, чисельність населення, Україна, Схід, прогноз.

\section{1. ВСТУП}

Постановка проблеми. Міграція населення - складний комплексний процес, що досліджується фахівцями багатьох спеціальностей: демографами, економістами, географами, істориками, етнографами, соціологами, юристами, статистами тощо. Говорячи про міграцію, передусім розрізняємо дві іï основні форми - стаціонарну міграцію, яка пов'язана зі зміною місця проживання та реєструється державною статистикою, та трудову міграцію - тимчасові поїздки на роботу за межі свого населеного пункту без зміни місця проживання [2]. Тривалий час міграція не охоплювалася безпековим дискурсом, оскільки погляд на безпеку обмежувався безпекою держави й загрозами геополітичного та воєнного характеру, тоді як міграцію розглядали як питання внутрішнє. Розширення погляду на безпеку відбулося порівняно недавно, коли після завершення холодної війни дедалі більшу увагу почали привертати не «жорсткі», тобто воєнні, а так звані «м’які» загрози безпеці, такі як деградація навколишнього середовища, наркоманія, злочинність, нелегальна міграція тощо [5]. На думку М. Вайнера, міграція та безпека пов'язані не лише прямим, а й зворотним зв'язком, тобто безпекові заходи держав впливають на переміщення населення [18, с. 253]. За обчисленнями О. Лавера, оцінки розмаху втрат населення країн СС від збройного насильства за період 20012020 рр. становлять 979 - 1129 - 1190 загиблих, із середньою цифрою втрат 1127 осіб. Військові втрати при цьому (утрати силовиків і терористів) становили 183 загиблі, або 16,27 \% від середньої цифри втрат [3].

Аналіз останніх досліджень і публікацій. Тематика міграційних процесів у ракусі конфліктогенності для України стала більш вагомою протягом останніх років, пов'язана 3 військовими подіями, що відбуваються на Сході нашої держави. Вагомий внесок у дослідження міграційних процесів зробили науковці Е. Лібанова [2], Г. Луцишин [4], О. Малиновська [5], О. Ровенчак [10], М. Романюк [11], У. Садова [15], М. Семенкова [13], Ю. Чайковський [16] й ін. 
Формулювання цілей статті. Мета дослідження - 3'ясування тенденції сучасних міграційних процесів України як чинника підвищення конфліктогенності та як результат конфлікту на Сході.

\section{2. РЕЗУЛЬТАТИ ДОСЛІДЖЕННЯ}

Виклад основного матеріалу й обгрунтування результатів дослідження. Основними тенденціями міграцій населення в Україні в період між останнім переписом населення колишнього СРСР (1989 р.) та першим переписом населення незалежної України (2001р.) стали:

- зниження загального рівня мобільності населення;

- зменшення інтенсивності міграційних зв'язків із колишніми республіками СРСР;

- розширення контактів із країнами пострадянського табору: потік еміграції з України до країн Європи, Америки та Ізраїлю, а також ротація навчальних мігрантів із країн, що розвиваються (повернення на батьківщину вихідців із відповідних країн, які закінчили навчання в закладах вищої освіти нашої країни, та заміна їх новими контингентами);

- набуття міграціями більш «сімейного» характеру - зменшення частки молоді й збільшення питомої ваги осіб середнього віку серед мігрантів, насамперед серед зовнішніх; значний міграційний приріст населення країни на рубежі 1980-1990-х рр., який змінився тривалим періодом перевищення вибуття над прибуттям (більш як на 100 тис. осіб щорічно), починаючи з 1994 р.;

- поява й розвиток нових для пострадянського простору форм міграційних переміщень: трудова міграція, рух біженців, транзит нелегальних мігрантів, повернення та облаштування представників раніше депортованих народів.

Після 2014 р. і подій на Донбасі та в Криму додалася ще одна причина - вимушена міграція внаслідок гібридної війни.

На сьогодні можемо визначити першу тенденцію міграційних процесів України - швидке скорочення населення. Чисельність населення України, що становило 1993 р. 52 млн осіб, унаслідок негативних тенденцій природного відтворення скоротилося майже на 10 млн. У 2010-2015 рр. природне скорочення становило в середньому понад 160 тис. на рік. За прогнозом Інституту демографії та соціальних досліджень НАН України, якщо показники народжуваності, тривалості життя й міграції залишаться незмінними, у 2050 р. в Україні буде 32 млн мешканців (рис. 1).

Друга тенденція - прибуття до нашої держави іммігрантів. Проблема 3 нелегальними мігрантами та біженцями загострює внутрішньополітич- 


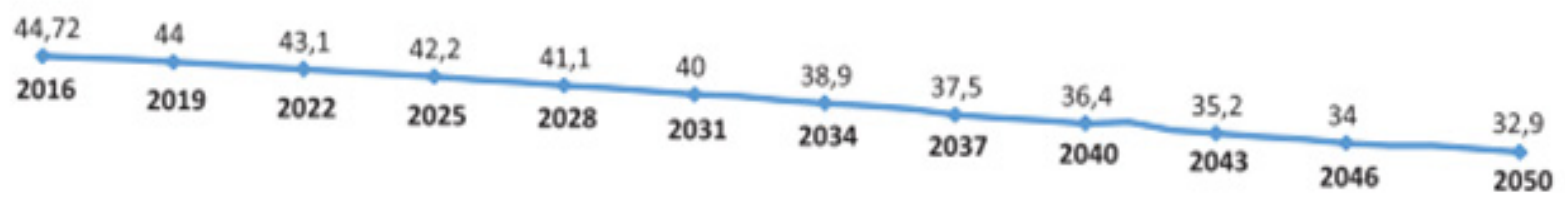

Рис. 1. Прогноз чисельності населення України за умови незмінних показників народжуваності, тривалості життя та мігращії, млн осіб [2] ну конфліктність, зокрема активізуються націоналістичні організації, які заявляють про те, що Європа й так уже втратила більшість своїх національних традицій і нинішня ситуація призведе до ще більшого розмивання ідентичності європейських націй. Недосконала політика інтеграції емігрантського населення в європейське суспільство призводить до загострення взаємин між корінним населенням європейських держав та іммігрантами, зростання анти-іммігрантських настроїв і масових протестів європейців проти міграційної політики національних урядів [4].

Бойові дії на Сході України, економічна криза й зниження рівня життя населення зменшили привабливість країни для іноземців. У 2014-2015 рр. іноземці відвідували Україну вдвічі менше, ніж у 2013 р. Кількість оформлених дозволів на імміграцію, що у 2010-2012 рр. становила 22-23 тис., у 2014 р. скоротилася до 20 тис., а у 2015 р. - до 16,6 тис. Окремою групою іноземців в Україні є біженці та особи, яким надано додатковий захист. Запровадження додаткового захисту 2011 р., напружена обстановка в Афганістані, звідки традиційно походить більшість іноземців, які отримали притулок в Україні, а також війна в Сирії зумовили певне збільшення чисельності біженців і користувачів додаткового захисту у 2012-2015 pр.

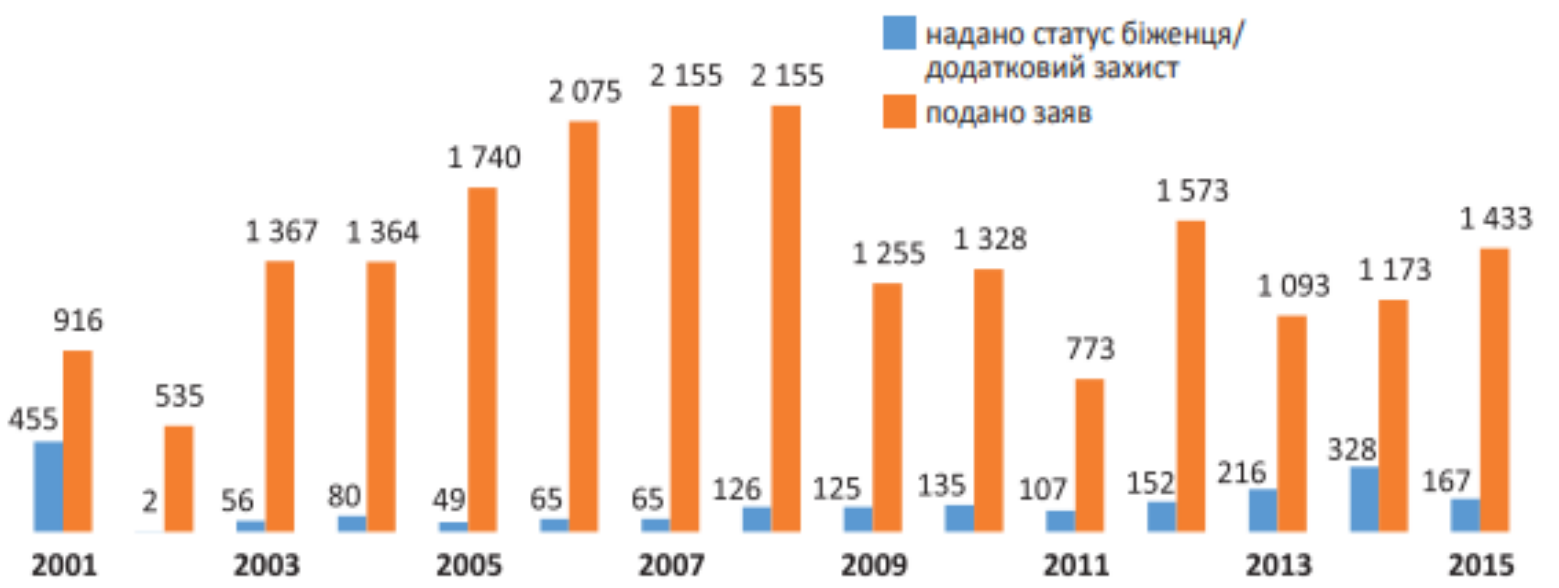

Рис. 2. Клопотання про надання статусу біжения та позитивні рімення за ними, 2001-2015 рр. [6] 
Ці ж обставини спричинили також збільшення кількості клопотань про набуття притулку. Найчастіше за притулком в Україні зверталися вихідці 3 Афганістану та Сирії. Водночас чисельність біженців в Україні залишається невисокою (рис. 2) [6].

Під терміном «біженець» розуміємо іноземця (або особу без громадянства), який унаслідок обгрунтованих побоювань стати жертвою переслідувань за ознаками расової, національної належності, ставлення до релігії або громадянства, належності до певної соціальної групи чи політичних переконань вимушений залишити територію держави, громадянином якого він $\epsilon$ (або на території якого він постійно проживає) i не може або не бажає користуватися захистом цієї країни внаслідок зазначених побоювань [16].

Гіпотеза Інституту демографії та соціальних досліджень НАН України полягає в тому, що найбільша кількість іммігрантів до України очікується з Афро-Азіатських країн (рис. 3). Подібна гіпотеза спирається на неминучість зменшення чисельності населення держави й об'єму пропозиції робочої сили в найближчому майбутньому. Представники азіатських та африканських етносів уже зараз проявляють бажання іммігрувати до України (у більшості країн Азії та Африки рівень життя населення значно нижчий). Якщо ж можливості поселення й проживання в нашій державі для вихідців Третього світу будуть кращими, ніж у Західних країнах, чисельність потенційних іммігрантів збільшиться настільки, що

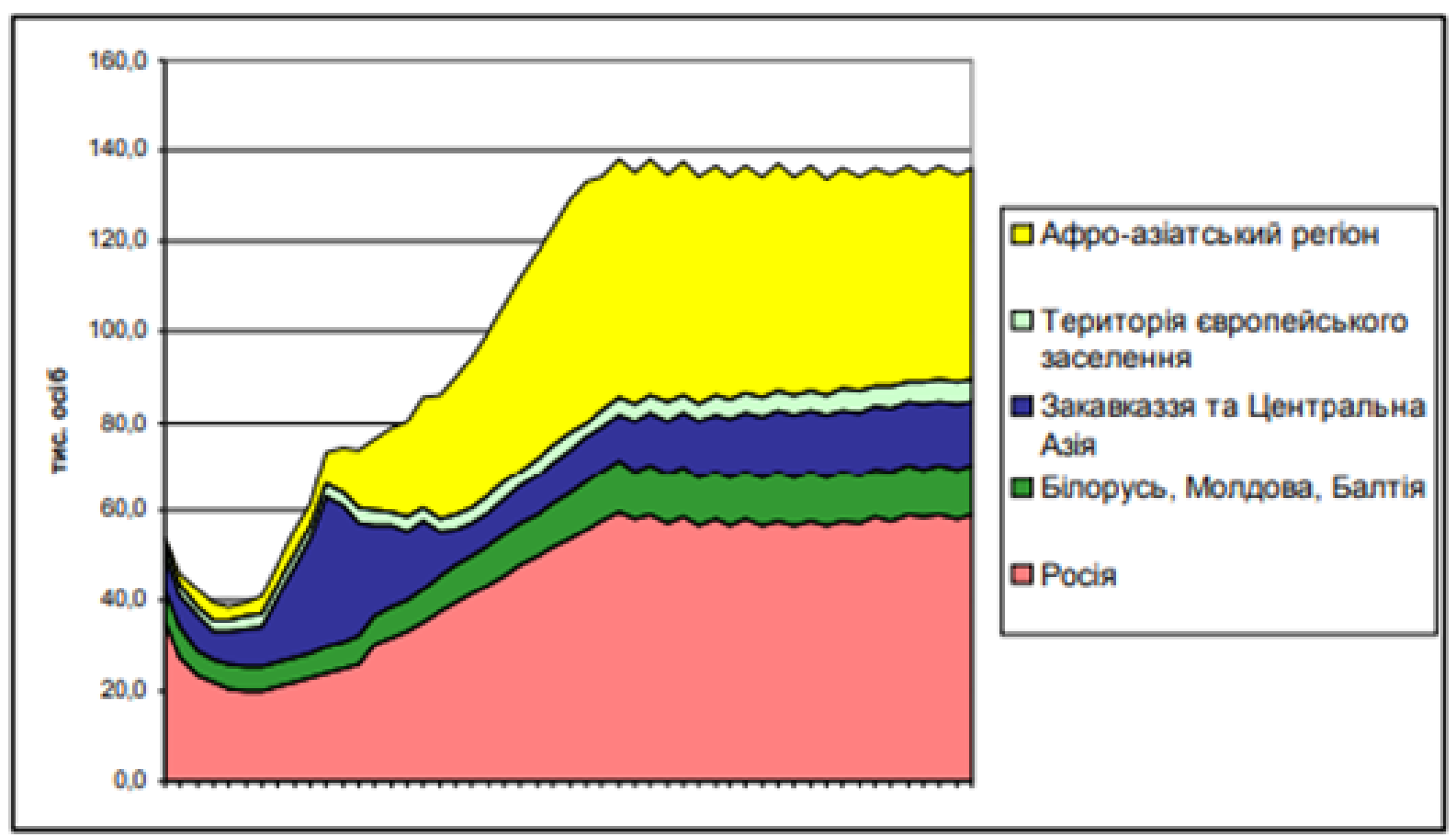

Рис. 3. Динаміка прибуття населення в Україну у 2000-2050 рр. (середній варіант прогнозу) [2] 
можна буде говорити про відбір бажаних контингентів.

Третя тенденція - потениійна конфліктогенність внутрішніх міграційних процесів та іiі вплив на безпекове середовище в країні. Зокрема, згідно з проведеним соціологічним дослідженням у 2015 р. (без урахування подій на Сході), щодо причин переселення українських внутрішньо переміщених осіб, а процес переселення відбувається без істотних соціальних конфліктів. Але аналіз, здійснений О. Міхеєвою та В. Середою, звертає увагу на наявність латентних конфліктів, які не проговорювалися респондентами під час прямих питань, однак проявлялись у відповідях на інші питання [8]. Ці латентні конфлікти пов'язані з відмінними моделями світосприйняття й емоційним фоном спілкування, насиченим стереотипами. Водночас ці стереотипи дуже часто нав'язані, за безпосереднього спілкування представників різних регіонів можуть якраз бути зруйнованими, що сприятиме кращому взаєморозумінню та

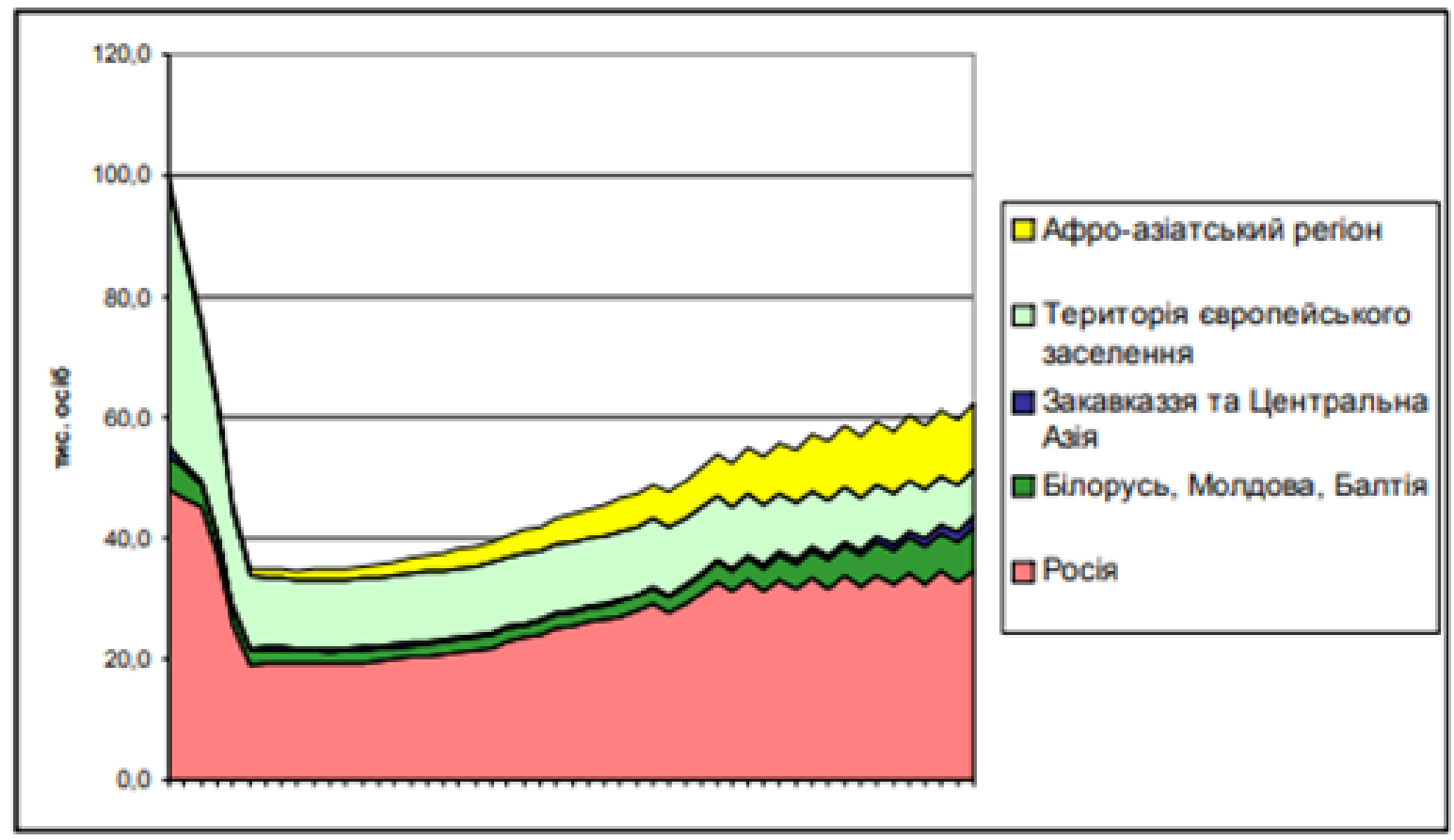

Рис. 4. Динаміка вибуття населення з Украӥни в 2000-2050 рр. (середній варіант прогнозу) [2]

консолідації суспільства [13].

Зворотним процесом є міграція українського населення до інших держав, тут тенденції й прогнози передбачаються таким чином, як представлено на рис. 4.

Четверта тенденція пов'язана з численними внутрішніми переселеннями в Україні, спричиненими анексією Криму та воєнними діями на Донбасі з 2014 р., що мають вимушений характер. За інформацією Міжві- 
домчого координаційного штабу 3 питань соціального забезпечення внутрішньо переміщених осіб (ВПО), станом на 2016 р. 3 непідконтрольних Уряду територій до інших регіонів України переміщено 1 млн 29 тис. 571 особу, у тому числі з Донецької й Луганської областей 1 млн 7 тис. 112 осіб та Автономної Республіки Крим і міста Севастополя 22 тис. 459 осіб, серед яких 170 тис. 581 дитина та 495 тис. 93 - особи з інвалідністю й похилого віку [7].

У результаті анексії Криму та військових дій на Донбасі у 20142015 рр. виник потік не лише внутрішньої, а й зовнішньої вимушеної міграції. Кількість клопотань про притулок, поданих громадянами України в європейських державах, перевищила у 2015 р. 22 тис., що було на третину більше, ніж 2014 р., і в понад 20 разів більше, порівняно з 2013 р. (рис. 5). Найбільше таких клопотань подано в Італії, Німеччині, Іспанії та Польщі. Водночас кількість поданих українцями заяв становила лише 1,7 \% усіх клопотань про притулок, поданих у країнах ЄС. До

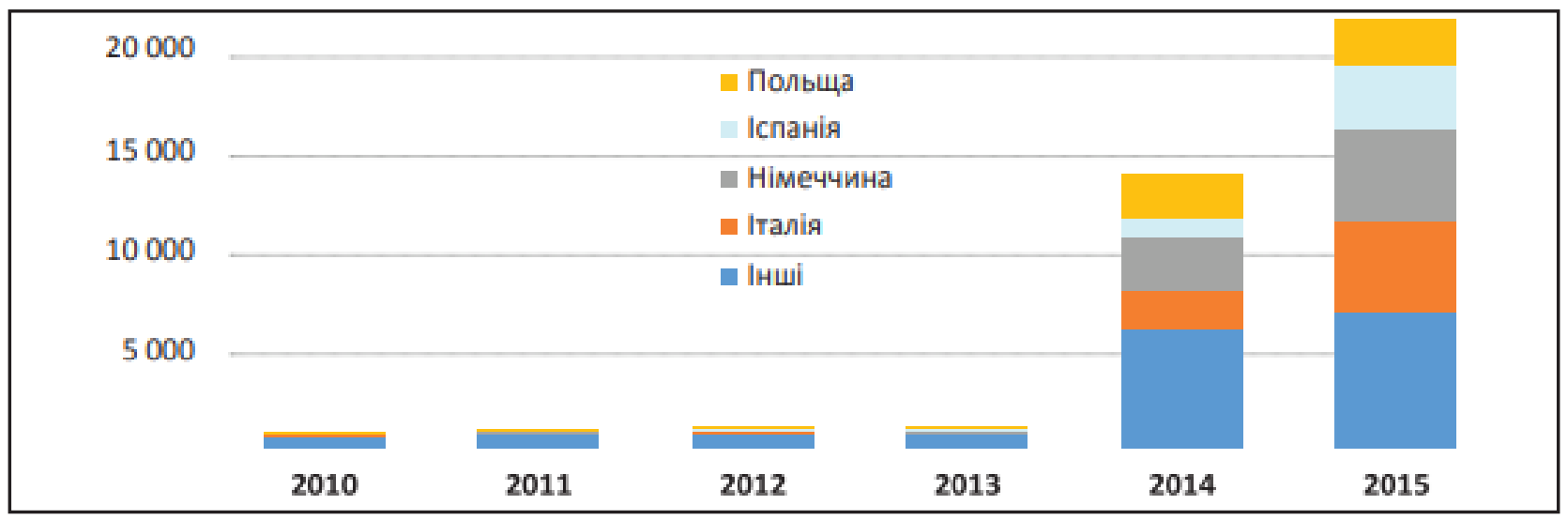

Рис. 5. Чисельність клопотань про притулок, поданих громадянами Украӥни в країнах СC, 2010-2015 рр. [6]

того ж лише нечисленні українці отримали позитивні рішення за своїми зверненнями. У 2015 р. статус біженця в країнах Євросоюзу відповідно до Женевської конвенції 1951 р. набули 415 громадян України, додаткову форму притулку за гуманітарними міркуваннями - 1150 осіб [17].

Після політичних потрясінь та економічної кризи, починаючи 3 2014 р., значні зміни в міграції та міграційних тенденціях українців справді ймовірні. Найпоширенішим видом міграції й водночас найчисленнішим світовим міграційним потоком завжди була та залишається трудова міграція. Грунтуючись на останніх дослідженнях Німецької консультативної групи в Україні, автори Д. Заха та М. Люкке підготували фактологічний аналіз недавніх змін у трудо- 
вій міграції українців, а також їх причин і наслідків (рис. 6). Вони зазначають, що спостерігається зміна вектора «Схід-Захід» щодо країн працевлаштування українських трудових мігрантів. За наведений у дослідженні час міграція до Росії зменшилася щонайменше на третину, а кількість мігрантів до Польщі зросла втричі до 0,5 млн. Зважаючи на велику кількість українських мігрантів в Італії та Чехії, Євросоюз $є$ найбільшим регіоном для працевлаштування мігрантів з України. Троє 3 чотирьох українських трудових мігрантів у 2017 р. працювали в країнах СС [9]. У 2019 р. трудова міграція з України вповільнилася, але не зрозуміло, чи це $є$ загальним уповільненням міграції. Можливо, це пов'язано зі зменшенням різниці в заробітній платі або відображає перехідні явища протягом виборчого року. Багато хто з українців - трудових мігрантів не проти залишитися назавжди в приймаючих країнах. Так, наприклад, опитування, проведене у 2020 р. в Польщі, показало, що назавжди в цій

\begin{tabular}{|c|c|c|c|c|}
\hline & \multicolumn{2}{|c|}{ Обстеження робочої сили (LFS) } & \multicolumn{2}{|c|}{ Дані країни-партнера** } \\
\hline & 2012 & 2017 & 2012 & 2017 \\
\hline \multicolumn{5}{|c|}{ Колишній СРСР } \\
\hline Білорусь & 21 & 22 & Дані відсутні & Дані відсутні \\
\hline Казахстан & Дані відсутні & Дані відсутні & Дані відсутні & Дані відсутні \\
\hline Росія & 510 & 343 & Дані відсутні & $346^{* *}$ \\
\hline \multicolumn{5}{|c|}{ Країни ЄC } \\
\hline Чехія & 152 & 123 & 103 & 116 \\
\hline Німеччина & 28 & 10 & 112 & 118 \\
\hline Італія & 156 & 147 & 225 & 235 \\
\hline Польща & 169 & 507 & 122 & 451 \\
\hline Португалія & 21 & 21 & 44 & 32 \\
\hline Іспанія & 53 & Дані відсутні & 78 & 89 \\
\hline 3агалом у $\in C$ & & & 779 & 1177 \\
\hline \multicolumn{5}{|c|}{ Інші } \\
\hline Ізраїль & Дані відсутні & 14 & Дані відсутні & Дані відсутні \\
\hline США & Дані відсутні & 23 & Дані відсутні & Дані відсутні \\
\hline Інші країни* & 70 & 93 & & \\
\hline Разом & 1182 & 1303 & & \\
\hline \multicolumn{5}{|c|}{$\begin{array}{l}\text { * - Різниця між загальною кількістю та переліченими країнами. Дані обстеження робочої сили } \\
\text { включають США, Ізраїль за } 2012 \text { рік, Іспанію за } 2017 \text { рік } \\
\text { ** - Дані щодо ЄС отримано з Єөростату, дані щодо Росії - з Росстату } \\
\text { Джерела: Сөітовий банк, Держстат, LFS } 2012 \text { року, LFS } 2017 \text { року, Єөростат, Poccmam }\end{array}$} \\
\hline
\end{tabular}

Рис. 6. Краӥни працевлаштування украӥнських мігрантів, тис. осіб [14] 
країні хотіли би залишитися 33 \% опитаних, у той час як у 2018 р. таке бажання висловили $22 \%$ опитуваних [14].

Унаслідок географічної близькості, родинних зв'язків, проросійської орієнтації частини мешканців Донецької та Луганської областей значна частина вимушених мігрантів із зони конфлікту на Сході країни виїхала до Росії. За даними Федеральної міграційної служби РФ, у 2015 р. за різних причин на території Росії зареєстровано 2,5 млн громадян України, або майже на мільйон більше, ніж на 1 січня 2014 р. [12]. На кінець 2015 р. на обліку перебували 273 громадянина України, яким надано статус біженця, і 311 тис. тих, які користувалися тимчасовим притулком [1].

Сьогодні основне стратегічне завдання полягає в збереженні державного суверенітету, територіальної цілісності України й інтеграції до європейського економічного та міграційного простору, забезпеченні наближених до світових стандартів якості й тривалості життя, реалізації прав і свобод громадян. Аналіз і врахування сучасних міграційних тенденцій у нашій державі в контексті участі України в європейському та світовому міграційному просторі розглядається як один із важливих чинників формування власної національної політики. Ця проблема перебуває в площині безпеки України [5]. Стрімка активізація міжнародної мобільності населення України, що відбувається за умов глобалізації та наростання інтенсивності світових міграцій, висуває актуальну проблему - регулювання міграційних процесів, надання їм організованого, безпечного й неконфліктного характеру.

\section{3. ВИСНОВКИ ТА ПЕРСПЕКТИВИ ПОДАЛЬШИХ ДОСЛІДЖЕНЬ}

Міграційні процеси, викликані необхідністю зміни місця постійного проживання під впливом збройного конфлікту всередині держави, $\epsilon$ найбільшим викликом сучасній міжнародній спільноті. Недосконалість міжнародно-правових норм у сфері міграції, а також неготовність i неспроможність держав самостійно впоратися з вимушеними міграційними потоками призводить до т. зв. «міграційних колапсів» (як їх називає Чайковський Ю.), коли проблема вимушених мігрантів посилюється iii несвоєчасним дозволом. Передусім, від таких вимушених збройним конфліктом міграційних потоків страждають сусідні 3 конфліктуючим держави, що змушує їх постфактум посилювати своє міграційне законодавство. Недобровільно переміщені люди в результаті військових, етнополітичних та інших конфліктів є однією 3 найбільш уразливих 
груп населення планети, й ураховує, що вимушена міграція може бути зовнішньою (особи, які шукають притулку, у тому числі біженці) i внутрішньою (переміщені особи, «внутрішні біженці»), поворотною та безповоротною, легальною й нелегальною. Україна внаслідок військового конфлікту 3 Росією зіткнулася 3 проблемою внутрішньої вимушеної міграції населення 3 окремих територій Донецької, Луганської областей та АР Крим до інших регіонів. Ситуація щодо внутрішньо переміщених осіб (ВПО) продемонструвала здатність усього суспільства до мобілізації. Погоджуємося $з$ позицією, висловленою групою науковців ДУ «Інститут регіональних досліджень імені М. І. Долішнього НАН України», котрі зазначили: в умовах, що склалися, Українська держава поставлена перед вимогою насамперед розв'язання двох найгостріших проблем установлення миру й забезпечення територіальної цілісності країни в умовах швидкої зміни міграційної ситуації.

\section{СПИСОК ВИКОРИСТАНИХ ДЖЕРЕЛ}

1. Главное управление по вопросам миграции МВД России. URL: https://гувм.мвд. pф/about/activity/stats/Statistics/Predostavlenie_ubezhishha_v_Rossijskoj.

2. Комплексний демографічний прогноз України на період до 2050 р. (кол. авторів)/ за ред. чл.-кор. НАНУ, д-ра. екон. наук, проф. Е. М. Лібанової. Київ: Укр. центр соц. реформ, 2006, 138 с.

3. Лавер, О. (2017). Етнічні конфлікти і міграційні процеси в країнах СС: соціологополітологічний аспект (2017-2020рр.). Геополітика Украӥни: історія і сучасність: зб. наук. праць, вип. 1 (24), 202, с .74-82.

4. Луцишин, Г. (2015). Міграційна криза в СС: проблема безпеки зовнішніх кордонів та загострення міжетнічних. Humanitarian vision, vol. 1, N. 2.

5. Малиновська, О. А. (2018). Міграційна політика: глобальний контекст та українські реалї: монографія. Київ: НІСД, 472 с.

6. Міграція в Україні: факти і изифри. Київ, 2016, 32 с.

7. Міжвідомчий координачійний штаб повідомляє. URL: http://www.dsns.gov.ua/ ua/Mizhvidomchiykoordinaciyniy-shtab.html

8. Міхеєва, О., Середа, В. (2015). Сучасні українські внутрішньо переміщені особи: основні причини, стратегії переселення та проблеми адаптації. Стратегії трансформації і превенції прикордонних конфліктів в Україні: зб. аналіт. матеріалів. Львів: Галицька вид. спілка, с. 9-49.

9. «Останній вимкне світло»: Якими є реальні масштаби трудової міграції 3 України до СС. Економічна правда, 11.02.2020. URL: https://www.epravda.com.ua/publications/2020/02/11/656895/

10. Ровенчак, О. (2006). Визначення та класифікації міграцій: наближення до топераційних понять. Політичний менеджмент, № 2, с. 127-139.

11. Романюк, М. Д. (2015). Міграційні загрози національній безпеці України: сучасні виклики, проблеми подолання. Демографія та соиіальна економіка, № 3 (25), 9-111. 
12. Сведения в отношении иностранных граждан, находящихся на территории РФ. URL: https://гувм.мвд.pф/about/activity/stats/Statistics/Svedenija_v_otnoshenii_inostrannih_grazh/item $/ 5850$

13. Семенкова, М. (2020). Особливості міграційних процесів під час збройного конфлікту на сході України і їх вплив на безпекове середовище. Enicmeмологічні дослідження в філософіï, сочіальних і політичних науках, 2020, 3(1), 233-240. https:// doi.org/10.15421/342024

14. Треть украинских работников мечтает остаться в Польше навсегда. Демоскоп Weekly, № 847-848, 17 февраля-1 марта.

15. Українська міграція в умовах глобальних і національних викликів XXI століття: наук. вид. / наук. ред. У. Я. Садова. Львів, 2019. 110 с.

16. Чайковський, Ю. (2016). Міграційні процеси у світлі збройних конфліктів: проблема міжнародно-правового регулювання. Вісник Луганського державного університету внутрішніх справ імені Е. О. Дідоренка, 1(73), 216-226.

17. Eurostat. Asylum and first time asylum applicants by citizenship, age and sex. URL: http://ec.europa.eu/eurostat/en/web/products-datasets/-/MIGR_ASYAPPCTZA.

18. Weiner M. (1995). The Global Migration crisis: Challenge to state and Human Rights. New York.

\section{TRENDS IN MIGRATION PROCESSES AS A FACTOR OF CONFLICTS GENERATION}

The article considers population migration as a complex complex process studied by specialists in many specialties. It is noted that migration and security are not only direct but also feedback, ie security measures of states affect the movement of the population. The main trends in population migration in Ukraine between the last census of the Soviet Union in 1989 and the first independent Ukraine in 2001 were: a decrease in the general level of population mobility; reducing the intensity of migration ties with the former Soviet republics; expanding contacts with the countries of the postSoviet camp; acquisition of more «family» migrations; emergence and development of new forms of migration movements for the post-Soviet space. After 2014 and the events in Donbass and Crimea, another reason was added - forced migration due to the hybrid war. The forecasts of changes in the population of Ukraine, migration of Ukrainians abroad and the arrival of migrants and refugees to our country by 2050 according to Ukrainian research institutes are considered.

Key words: migration processes, refugees, conflict, population, Ukraine, East, forecast. 


\section{REFERENCES}

1. Main Directorate for Migration of the Ministry of Internal Affairs of Russia. URL: https://гувм.мвд.pф/about/activity/stats/Statistics/Predostavlenie_ubezhishha_v_Rossijskoj.

2. Comprehensive demographic forecast of Ukraine for the period up to 2050 (team of authors) / ed. Corresponding Member NASU, Doctor of Economics, Prof. E. M. Lebanon. Kyiv: Ukrainian Center for Social Reforms, 2006, 138 p.

3. Laver, O. (2020). Ethnic conflicts and migration processes in the EU: sociological and political science aspect (2017-2020). Geopolitics of Ukraine: history and modernity: Collection of scientific works, 1 (24), 202, pp. 74-82/

4. Lutsyshyn, G. (2015). Migration crisis in the EU: the problem of security of external borders and exacerbation of interethnic. Humanitarian vision, 1, N. 2.

5. Malinovskaya O. A. (2018). Migration policy: global context and Ukrainian realities: monograph. Kyiv: NISD, 472 p.

6. Migration in Ukraine: facts and figures. Kyiv, 2016, 32 p.

7. The interagency coordination headquarters shall report. URL: http://www.dsns.gov. ua/en/Mizhvidomchiykoordinaciyniy-shtab.html

8. Mikheeva, O., Sereda, V. (2018). Modern Ukrainian internally displaced persons: the main causes, resettlement strategies and adaptation problems. Strategies for Transformation and Prevention of Border Conflicts in Ukraine. Collection of analytical materials. Lviv: Galician Publishing Union, 9-49.

9. «The latter will turn off the light»: What is the real scale of labor migration from Ukraine to the EU. Economic truth, 11.02.2020. URL: https://www. althoughda.com.ua/ publications/2020/02/11/656895/

10. Rovenchak, O. (2006). Definition and classification of migrations: approximation to operational concepts. Political Management, 2, p. 127-139.

11. Romanyuk, M. D. (2015). Migration threats to national security of Ukraine: current challenges, problems of overcoming. Demography and Social Economy, 3 (25), 9-111.

12. Information regarding foreign citizens in the territory of the Russian Federation. URL: https: //guvm.mvd.rf/about/activity/stats/Statistics/Svedenija_v_otnoshenii_inostrannih_grazh/item/5850

13. Semenkova, M. (2020). Features of migration processes during the armed conflict in eastern Ukraine and their impact on the security environment. Epistemological Research in Philosophy, Social and Political Sciences, 3 (1), 233-240. https://doi.org/10.15421/342024

14. One third of Ukrainian workers dream of staying in Poland forever. Weekly Demoscope, 47847-848, February 17 - March 1.

15. Ukrainian migration in the context of global and national challenges of the XXI century: a scientific publication / science. ed. U. Ya. Sadova. Lviv, 2019, 110 p.

16. Tchaikovsky, Y. (2016). Migration processes in the light of armed conflicts: the problem of international legal regulation. Bulletin of Luhansk State University of Internal Affairs named after E. O. Didorenko, 1 (73), 216-226. 